\title{
AMARAL, D. Enquanto Salazar dormia... 9. ed. Alfragide: BIS, 2019.
}

\author{
Diogo Fernandes Sousa \\ Colégio Nossa Senhora da Esperança, Porto / Portugal \\ Externato das Escravas do Sagrado Coração de Jesus, Porto / Portugal \\ diogo.sousa@cnse.pt \\ https://orcid.org/0000-0002-9520-1336
}

O livro intitulado Enquanto Salazar dormia... constitui-se uma incursão histórica, envolta num romance, ao Portugal do período da Segunda Guerra Mundial, possibilitando uma perceção do ambiente sentido no país, das repercussões da guerra em Portugal, da posição assumida por Portugal nessa mesma guerra, das posições da elite nacional face à guerra, e das ambiguidades do regime do Estado Novo e suas implicações no dia a dia dos portugueses.

Com efeito, podemos considerar, neste romance histórico de Domingos Amaral, uma multiplicidade de ilações passíveis de reflexão às feições da sociedade portuguesa e às posições assumidas por Portugal e pelo Estado Novo, nomeadamente por Salazar, enquanto representante máximo do regime.

É importante sublinhar que o autor, Domingos Amaral, é formado em Economia e em Relações Económicas Internacionais, contudo destaca-se na sua produção literária pela publicação de vários romances, muitos dos quais com a particularidade de apresentarem evidências históricas sobre os períodos descritos nos mesmos. Igualmente, importa destacar que o romance histórico em análise, Enquanto Salazar dormia..., encontra-se editado em Portugal, mas também, no Brasil, Polónia e Itália.

Tendo em consideração as particularidades vividas em cada momento histórico descrito no romance e as várias paixões desenvolvidas pelo personagem principal, que narra o desenlace da história, a presente edição encontra-se dividida em três partes, antecedidas de um prólogo e sucedidas de uma nota final. 
No prólogo, conseguimos contextualizar a narração num período temporal específico da década de 90 do século XX, e num espaço determinado onde se vai desenrolar o principal da ação, que corresponde a Lisboa, enquanto na nota final, o autor realça que a maioria dos factos são baseados em factos verídicos, nomeadamente no que concerne à espionagem, em Portugal, durante a Segunda Guerra Mundial, às batalhas aéreas e às redes de espionagem relatadas e à personalidade e atuação de vários personagens históricos presentes na narrativa.

A primeira parte está associada a Mary; a segunda parte destinada à paixão por Alice; e a terceira parte à ligação com Anika. Todas estas personagens femininas são muito importantes na narrativa seguida pelo autor e tem uma participação direta na perceção do período temporal que lhes corresponde.

Em todas as partes, o texto percorre uma linha cronológica de acontecimentos, fazendo alguns paralelos com o período contemporâneo do narrador/personagem principal da história. Possibilita a compreensão ao leitor de que todo o desenlace histórico é uma recordação do personagem principal, muitas das vezes ao ser partilhada com o seu neto.

No que respeita ao ambiente vivido no país neste período e às repercussões da guerra em Portugal, constate-se o seguinte exemplo, que demonstra que a guerra era vivida de uma forma diferente, baseada em meios de propaganda de informação, como os jornais ou o cinema. Também, demonstrativo que Portugal recebeu despojos da guerra, aludindo por exemplo à receção de refugiados, em particular, da população judaica que necessitou de fugir das perseguições nazis e que, muitas das vezes, perderam rios de dinheiro para garantir a sua sobrevivência:

[...] Mas também o ambiente de Lisboa, em 1941, era quase cómico. Por momentos, pensei em dizer tragi-cómico, mas o trágico seria exagero. Trágico era o que se passava em Inglaterra, com os bombardeamentos das cidades. Trágico era o que se passava no Norte de África, com a guerra no deserto. Ali, nas ruas de Lisboa, a guerra não era "A GUERRA", com mortos e feridos. Era uma guerra diferente: era o eco de uma guerra, eram os despojos de uma guerra, eram os absurdos políticos e económicos de uma guerra, era a psicologia negra de uma guerra, mas não era "A GUERRA" [...]. (AMARAL, 2019, p. 19) 
Relativamente às repercussões da guerra em Portugal, o próximo exemplo é ilustrativo da forma como a evolução da guerra influenciava o pensamento da população portuguesa e impactava nas suas vidas, particularmente na vertente económica:

[...] Em Portugal, as perspectivas não eram as melhores. O partido germanófilo continuava eufórico, os partidários dos aliados acabrunhados. A Gestapo e a Abwher actuavam livremente, enquanto a PVDE fechava os olhos. E a situação económica piorara, sendo que a população portuguesa começava a culpar os ingleses das dificuldades, acusando o bloqueio naval imposto por Churchill. [...]. (AMARAL, 2019, p. 163)

No que se refere à posição das elites nacionais, seguindo as orientações da posição do país e de Salazar face ao envolto histórico, podemos perceber, através do exemplo, que famílias da elite nacional, transpunham as ideias escutadas dentro da esfera militar e política portuguesa:

[...] O general Joaquim Silva admirava a capacidade industrial e militar da Alemanha, os seus aviões e submarinos, a sua arquitectura grandiosa. Porém, considerava Hitler um “megalómano". (AMARAL, 2019, p. 52)

[.... Os dois irmãos de Carminho, Luís e António, ambos militares, idolatravam Mussolini e Hitler, esforçando-se por moderar as excitações anglófilas do pai. [...]. (AMARAL, 2019, p. 53)

Por fim, no que respeita às ambiguidades do regime do Estado Novo e às implicações do regime no dia a dia dos portugueses, o pensamento de Salazar foi manter a neutralidade na guerra, contudo em função da evolução bélica surgiam acontecimentos difíceis de controlar que exigiam uma flexibilidade constante para agradar, tanto às forças do Eixo, como aos Aliados:

[...] Como seria de esperar, o regime de Salazar farejou o perigo. Numa situação de equilíbrio militar entre o Eixo e os Aliados, era mais fácil manter a neutralidade. Com as mudanças na guerra, emergiam como possíveis vencedores os russos, os americanos e os ingleses, cujos regimes eram perigosos para Salazar. Além disso, 
a pressão dos Aliados agudizou-se, exigindo-lhe que terminasse a exportação de volfrâmio para a Alemanha e que cedesse, nos Açores, a utilização das Lajes. (AMARAL, 2019, p. 238)

Todos os elementos que temos vindo a assinalar permitem-nos concluir o grau de verosimilhança desta obra em relação aos factos nela retratados, possibilitando, desse modo, a compreensão da atuação de Portugal na Segunda Guerra Mundial e a vivência da sociedade portuguesa contemporânea a este período histórico.

Data de recebimento: 17 de agosto de 2021.

Data de aprovação: 24 de outubro de 2021. 